\title{
INTERNATIONAL LEGAL SCHOLARSHIP AND THE QUEST FOR INTEGRATING DEMOCRATIC AND PARTICIPATORY PRINCIPLES IN THE DEFINITION OF GLOBAL PUBLIC GOODS
}

Eva Kassoti*

\begin{abstract}
This contribution purports to critically examine the ways in which modern international legal scholarship has come to grips with the question of bridging the 'democratic participation gap' in the context of defining and prioritising global public goods. It begins by asserting that core tenets of legal positivism, such as State sovereignty and consent, are deeply undemocratic, or that, at a minimum, they are capable of operating in a deeply undemocratic way, thereby casting doubt on whether classic international law can be seen as the solution to the problem of democratic participation. Against this background, the article continues by exploring two alternative theoretical frameworks for bridging the 'participation gap'. The global administrative law project is examined and rejected as its main focus on accountability, rather than democracy, implies that it lacks ambition when it comes to the question of broadening decision-making processes. The focus turns next to global constitutionalism. It is argued that, in reality, this version of constitutionalism does not really offer any new analytical and normative insights; traditional legal thinking is anything but unfamiliar with the conceptual distinction between direct and indirect participation. The article concludes by canvassing some remarks on a common mindset of the discipline: the discipline's knee-jerk response to the challenge of defining global public goods illustrates the unease felt by international lawyers to deal with questions of global governance without transferring them into the realm of law.
\end{abstract}

\section{A. INTRODUCTION}

Although the concept of global public goods, initially rooted in economic theory, has entered into the policy discourse of a number of important international organisations over the past two decades, international legal scholars are relative latecomers to the debate. Only recently have international lawyers begun to seriously grapple with the challenge of identifying and defining common goods that transcend national boundaries. Current theorising has focused on the so-called 'democratic participation gap', namely on the idea that one of the main challenges of extrapolating the concept to the global level is the under-representation of many potentially affected stakeholders (such as groups of States, civil society actors and even individuals) in the decision-making processes surrounding the definition and provision of these goods. In this vein, it has been asserted that global public goods cannot be defined in a democratic and legal vacuum and, thus, different accounts of how the discipline ought to contribute to the

\footnotetext{
* Eva Kassoti (PhD), Senior Lecturer in Law, The Hague University of Applied Sciences. E.Kassoti@hhs.nl.
} 
integration of democratic and participatory principles in the definition of global public goods have been offered.

In this light, this contribution purports to critically examine the ways in which modern international legal scholarship has come to grips with the question of bridging the 'democratic participation gap' in the context of defining and prioritising global public goods and global commons. The article begins by asserting that core tenets of legal positivism, such as State sovereignty and consent, are deeply undemocratic, or that, at a minimum, they are capable of operating in a deeply undemocratic way, thereby casting doubt on whether classic international law can be seen as the solution to the problem of democratic participation. Against this background, the article continues by exploring two alternative theoretical frameworks for bridging the 'participation gap'. The global administrative law project is examined and rejected as its main focus on accountability, rather than democracy, implies that it lacks ambition when it comes to the question of broadening decision-making processes.

The article turns next to global constitutionalism. The project's principal emphasis on global values, such as democracy and inclusiveness, seemingly makes it the perfect heuristic device for integrating democratic ideals in the definition of global public goods. However, it is argued that recourse to global constitutionalism is not without problems. This school of thought acknowledges that the indirect involvement of non-State actors in decision-making can enhance the legitimacy of global governance, and thus, it advocates in favour of broadening, structuring and streamlining the role of non-governmental organisations ('NGOs') in international decision-making processes. More particularly, Anne Peters argues in favour of retaining the distinction between legal subjects and social actors that may indirectly influence decision-making processes since this distinction is crucial in maintaining stability and predictability in international relations. It is doubtful whether Peters' version of constitutionalism - that has recently gained traction as it stays closer to mainstream legal thinking - can offer additional insights on how international law could become more conducive to filling the 'participation gap'. The article argues that, in reality, this version of constitutionalism does not really offer any new analytical and normative insights; traditional legal thinking is anything but unfamiliar with the conceptual distinction between direct and indirect participation.

The article ultimately raises the question of the usefulness of addressing the challenge of defining global public goods from the vantage point of international law. It is argued that, presently, international law and international legal scholarship are of limited assistance in redressing the participation gap in the definition of global public goods. The article concludes 
by canvassing some remarks on a common mindset of the discipline: the discipline's knee-jerk response to the challenge of defining global public goods illustrates the unease felt by international lawyers in dealing with questions of global governance without transferring them into the realm of law. The article stresses that, as international legal scholars, we should be more open to the limitations of our own discipline and accept that we can grapple with new phenomena without necessarily apprehending them as legal phenomena.

\section{B. BACKGROUND TO THE CONCEPT OF GLOBAL PUBLIC GOODS}

The concept of public goods is rooted in economic theory and denotes goods that are non-rival and non-excludable, in the sense that everyone can use them without diminishing their availability to others (non-rivalry) and that no one can be practically excluded from using them (non-excludability). ${ }^{1}$ An oft-cited example of a public good is a lighthouse; everyone can benefit from its light without diminishing its availability to others and no one can be prevented from using it. Until recently the concept of public goods remained within the frame of reference of the nation-State; the relevant debate assigned State institutions an important role in financing and producing public goods and the provision of such goods was seen as the main reason for the existence of the State. ${ }^{2}$ However, over the past two decades, the concept of public goods has assumed a prominent role in global policy discourse largely as a result of the efforts of the United Nations Development Program ('UNDP') Office of Development which published three books on the topic of 'global public goods' ('GPGs') in 1999, ${ }^{3} 2003^{4}$ and $2006 .{ }^{5}$ During the same period, France and Sweden created an International Task Force on GPGs which published its report in $2006 .{ }^{6}$ The extrapolation of the concept to the global level has been accompanied by a reconfiguration of its scope. The UNDP describes GPGs not only in terms of non-rivalry and non-excludability, but also as goods that provide benefits to everyone worldwide irrespective of their socio-economic status. ${ }^{7}$ Inge Kaul et al describe

\footnotetext{
${ }^{1}$ Inge Kaul, Isabelle Grunberg and Marc Stern, 'Defining Global Public Goods' in Inge Kaul, Isabelle Grunberg and Marc Stern (eds), Global Public Goods: International Cooperation in the $21^{\text {st }}$ Century (OUP 1999) 2-3.

${ }^{2}$ Meghnad Desai, 'Public Goods: A Historical Perspective' in Inge Kaul and others (eds), Providing Global Public Goods: Managing Globalization (OUP 2003) 63-65; Mancur Olson, The Logic of Collective Action: Public Goods and the Theory of Groups (HUP 1965) 15.

3 ibid.

${ }^{4}$ Kaul and others (n 2).

${ }^{5}$ Inge Kaul and Pedro Conceição (eds), The New Public Finance: Responding to Global Challenges (OUP 2006).

${ }^{6}$ International Task Force on Global Public Goods, 'Meeting Global Challenges: International Cooperation in the National Interest' (2006)

<ycsg.yale.edu/sites/default/files/files/meeting_global_challenges_global_public_goods.pdf> accessed 15 August 2017.

${ }^{7}$ Kaul, Grunberg and Stern (n 1) 16.
} 
GPGs as 'outcomes (or intermediate products) that tend toward universality in the sense that they benefit all countries, population groups and generations. ${ }^{8}$ In the same vein, the International Task Force on GPGs describes GPGs as "those whose benefit could in principle be consumed by the governments and peoples of all states. ${ }^{, 9}$ On this basis, the concept now covers a wide array of global issues including environmental protection, ${ }^{10}$ cultural heritage, ${ }^{11}$ health, ${ }^{12}$ knowledge, ${ }^{13}$ peace ${ }^{14}$ and distributive justice. ${ }^{15}$ A number of important international actors, such as the European Union, ${ }^{16}$ the World Health Organization ${ }^{17}$ and the World Bank ${ }^{18}$ have recognised the growing importance of GPGs. The concept has gained traction in the international arena largely because it can be used as a legitimising instrument for the everexpanding role of international institutions. As Bodansky explains: 'For international organizations, global public goods ... provide a response to the growing questions that emerged in the 1990s about their legitimacy. ${ }^{19}$ Recasting a global policy challenge in terms of 'global goods' provides a powerful argument in favour of increased co-operation and regulation..$^{20}$ For instance, recasting the problem of climate change in terms of reduction of greenhouse gas emissions accentuates the need for collective action at the international level. As the argument goes, just as the State is considered crucial in providing public goods at the national level, international governance is crucial for the provision of global public goods. ${ }^{21}$

International legal scholars are relative newcomers to the debate; only recently have international lawyers begun to seriously grapple with the challenges posed by common goods that transcend national boundaries. International law can be (and has been) seen both as

\footnotetext{
8 ibid.

${ }^{9}$ International Task Force on Global Public Goods (n 6) x.

${ }^{10}$ Scott Barrett, 'Montreal versus Kyoto: International Cooperation and the Global Environment' in Kaul, Grunberg and Stern (n 1) 192.

${ }^{11}$ I Serageldin, 'Cultural Heritage as Public Good: Economic Analysis Applied to Historic Cities' in Kaul, Grunberg and Stern (n 1) 240.

${ }^{12}$ Lincoln C Chen, Tim G Evans and Richard A Cash, 'Health as a Global Public Good' in Kaul, Grunberg and Stern (n 1) 284.

${ }^{13}$ Joseph E Stiglitz, 'Knowledge as a Global Public Good' in Kaul, Grunberg and Stern (n 1) 308.

${ }^{14}$ Ruben P Mendez, 'Peace as a Global Public Good' in Kaul, Grunberg and Stern (n 1) 382.

${ }^{15}$ Ethan B Kapstein, 'Distributive Justice as a Global Public Good' in Kaul, Grunberg and Stern (n 1) 88.

${ }^{16}$ European Commission, 'EU Focus on Global Public Goods' $<$ ec.europa.eu/environment/archives/wssd/pdf/publicgoods.pdf> accessed 15 August 2017.

${ }^{17}$ WHO, 'Global Public Goods and Health: Concepts and Issues' (2016) $<$ www.who.int/trade/distance_learning/gpgh/gpgh1/en/> accessed 15 August 2017.

${ }^{18}$ Development Committee, 'Global Public Goods: A Framework for the Role of the World Bank' DC $2007-$ 0020 (28 September 2008) <www.cbd.int/financial/interdevinno/wb-globalpublicgoods2007.pdf> accessed 15 August 2017.

${ }^{19}$ Daniel Bodansky, 'What's in a Concept? Global Public Goods, International Law and Legitimacy' (2012) 23 EJIL 651, 655.

${ }^{20}$ ibid.

21 ibid. See also generally Daniel Bodansky, 'The Legitimacy of Global Governance: A Coming Challenge for International Environmental Law?’ (1999) AJIL 596.
} 
potential facilitator of and as potential constraint on the effective provision of GPGs. Schaffer ${ }^{22}$ and Bodansky ${ }^{23}$ argue that international law can play an important role in the production and provision of these goods. At the other end of the spectrum, authors such as Krisch ${ }^{24}$ and Petersmann ${ }^{25}$ have cast doubt on the ability of international law to tackle the challenge of GPGs. Authors belonging to this school of thought claim that the consent-based structure of international law (both in terms of incurring obligations and in terms of enforcement) prevents it from effectively countering the free-riding and collective action problems often associated with the provision of GPGs. ${ }^{26}$ This line of critique echoes the concern raised in non-legal scholarship over the hurdles of the 'Westphalian decision-making processes'. The economist, Nordhaus, has stressed that:

[T]he Westphalian system leads to severe problems for global public goods. The requirement for unanimity is in reality a recipe for inaction ... To the extent that global public goods may become more important in the decades ahead, one of our major challenges is to devise mechanisms that overcome the bias toward the status quo and the voluntary nature of current international law in life-threatening issues. To someone who is an outsider to international law, the Westphalian system seems an increasingly dangerous vestige of a different world. ${ }^{27}$

Similarly, the International Task Force on Global Public Goods identified State sovereignty as one of the main problems hindering the effective provision of GPGs. ${ }^{28}$

However, the picture is not as bleak as it may seem at first glance. Although international law lacks strong enforcement mechanisms - thereby being of limited assistance in addressing issues of free-riding - the contributions by Schaffer and Bodansky show that GPGs entail different problem-types ${ }^{29}$ and that, as a result, there is a varying role for international law in

\footnotetext{
${ }^{22}$ Gregory Shaffer, 'International Law and Global Public Goods in a Legal Pluralist World' (2012) 23 EJIL 669.

${ }^{23}$ Bodansky (n 19).

${ }^{24}$ Nico Krisch, 'The Decay of Consent: International Law in an Age of Global Public Goods' (2014) 108 AJIL 1.

${ }^{25}$ Ernst-Ulrich Petersmann, 'Introduction and Overview: Lack of Adequate Theories, Rules and Institutions for the Central Policy Challenge in the 21 ${ }^{\text {st }}$ Century?' in E-U Petersmann (ed), Multilevel Governance of Interdependent Public Goods: Theories, Rules and Institutions for the Central Policy Challenge in the $21^{\text {st }}$ Century, EUI Working Paper RSCAS 2012/23 (2012) $<$ cadmus.eui.eu/bitstream/handle/1814/22275/RSCAS_2012_23final.pdf? sequence $=2 \&$ isAllowed $=\mathrm{y}>$ accessed 15 August 2017.

${ }^{26}$ Krisch (n 24) 3; Andrew T Guzman, 'Against Consent' (2012) 52 Va J IntL L 747, 749.

27 W D Nordhaus, 'Paul Samuelson and Global Public Goods' (5 May 2005) 8, $<$ http://www.econ.yale.edu/ nordhaus/homepage/PASandGPG.pdf $>$ accessed 15 August 2017.

${ }^{28}$ International Task Force on Global Public Goods (n 6) xi.

${ }^{29}$ For the different types of GPGs see generally Scott Barrett, Why Cooperate? The Incentive to Supply Global Public Goods (OUP 2007).
} 
producing different types of these goods. ${ }^{30}$ For aggregate effort GPGs (namely GPGs that can only be produced through the collective action of multiple States) ${ }^{31}$ international law could provide different fora for negotiations in the form of international institutions as well as a learning process for the evaluation of the costs and benefits of producing these goods. ${ }^{32}$ For weakest link GPGs (which involve a holdout problem in the sense that the benefit of the GPG is provided only if all States participate $)^{33}$ international law could provide solutions either through co-operation (eg providing assistance through international institutions to 'weak' States to produce the GPG), or through coercion (eg imposing economic or other types of sanctions in cases of States that are unwilling to co-operate in the provision of GPGs). ${ }^{34} \mathrm{On}$ the other hand, in the case of single best effort GPGs (in the sense of goods that do not require for their solution the aggregate effort of a group but rather depend on the single best effort of an individual actor $)^{35}$ international law and international institutions can play a role in decisions over implementation by constraining unilateral action. ${ }^{36}$

At the same time, it has been pointed out that most of the existing scholarship focuses on issues related to the provision of GPGs, whereas the question of which goods to provide in the first place has largely remained at the margins of scholarly attention. ${ }^{37}$ It needs to be noted that defining what amounts to a 'global public good' is never neutral, but rather it constitutes a matter of policy choice. ${ }^{38}$ As the International Task on Global Public Goods has conceded: 'A critical reality of global public goods is that they are contested; states have different interests, values and preferences, even when they share long-term goals. ${ }^{39}$ Climate engineering provides a good example; some argue that it should be conceptualised as a global public good as it could have positive effects on slowing climate change, whereas others consider it as dangerous and immoral. ${ }^{40}$ Cogolati, Hamid and Vanstappen argue that the question of what constitutes a GPG should not be answered 'in a democratic and legal vacuum. ${ }^{41}$ In this vein, they have drawn

\footnotetext{
${ }^{30}$ Shaffer (n 22); Bodansky (n 19).

${ }^{31}$ Barrett (n 29) 5-7. Barrett offers as an example of an aggregate effort public good combating climate change.

32 Shaffer (n 22) 679; Bodansky (n 19) 659-660.

${ }^{33}$ Barrett (n 29) 3-5. Barrett offers as an example of a weakest link public good smallpox eradication.

${ }^{34}$ Shaffer (n 22) 679; Bodansky (n 19) 660-663.

${ }^{35}$ Barrett (n 29) 2-3. Barrett offers as an example of a single best shot effort GPG the deflection of an asteroid headed for a direct hit with Earth.

${ }^{36}$ Shaffer (n 22) 679; Bodansky (n 19) 663-665.

${ }^{37}$ Samuel Cogolati, Linda Hamid and Nils Vanstappen, 'Global Public Goods and Democracy in International Legal Scholarship' (2016) 5 CJICL 4, 20-21.

${ }^{38}$ Inge Kaul and Ronald U Mendoza, 'Advancing the Concept of Global Public Goods' in Kaul and others (n 2) 104.

${ }^{39}$ International Task Force on Global Public Goods (n 6) 86.

${ }^{40}$ Bodansky (n 19) 656.

${ }^{41}$ Cogolati, Hamid and Vanstappen (n 37) 5.
} 
attention to the little explored link between GPGs, democracy and international law and have highlighted the need to engage more deeply with 'the role that international law could play in guaranteeing a democratic decision-making process on GPGs.' ${ }^{42}$ The call for expanding the research agenda on GPGs to include considerations of democracy is substantiated, inter alia, with reference to the UNDP study on GPGs. ${ }^{43}$ The study underscores that one of the main weaknesses of the current governance architecture hindering the effective provision of GPGs is the so-called 'participation gap', ie the exclusion of those affected by decisions on GPGs from the decision-making processes regarding their definition. ${ }^{44}$ The Commission also refers to the 'participation gap' as one of the main deficits of the existing policy-making mechanisms at the international level. According to the Commission: 'Agreements on which GPGs should be given priority are political choices in which the maximum involvement of all those affected is crucial. ${ }^{45}$ In this light, the remainder of the article explores whether, and if so to what extent, international law can help reduce the democratic deficit in the definition of GPGs. For this purpose, the next section begins by making some preliminary points regarding the relationship between democracy and international law.

\section{DEMOCRACY AND INTERNATIONAL LAW}

Democracy both as a constitutional principle and as a political process is a contentious concept that has undergone significant changes throughout history. ${ }^{46}$ Article 25 of the International Covenant on Civil and Political Rights ${ }^{47}$ ('ICCPR') reflects the internationally agreed minimum normative content of the principle. ${ }^{48}$ The Article grants every citizen the right to take part in the conduct of public affairs, either directly or through freely chosen representatives as well as the right to 'vote and be elected at genuine periodic elections.' According to Crawford, art 25 of the ICCPR:

\footnotetext{
42 ibid 20.

43 ibid.

${ }^{44}$ Inge Kaul, Isabelle Grunberg and Marc Stern, 'Introduction' in Kaul, Grunberg and Stern (n 1) xxvi.

${ }^{45}$ European Commission (n 16).

${ }^{46}$ Hilary Charlesworth, 'Democracy and International Law' (2014) 371 Recueil des Cours de l'Académie de Droit International 53, 54-69.

47 International Covenant on Civil and Political Rights (adopted on 16 December 1966, entered into force 23 March 1976) 999 UNTS 171 (ICCPR).

48 James Crawford, 'Democracy and International Law' (1993) 63 BYIL 113, 113-114. The idea that democracy entails popular participation in and control over decisions also finds support in the writings of Marks and Gould. See Susan Marks, The Riddle of All Constitutions (OUP 2000) 109; Carol Gould, 'The Human Right to Democracy and Its Global Import' in Cindy Holder and David Reidy (eds), Human Rights: The Hard Questions (CUP 2013) 292. ICCPR art 25 is reflected at the regional level in Protocol I of the European Convention on Human Rights (adopted 20 March 1952, entered into force 18 May 1954) 213 UNTS 262 art 3, and in the American Convention on Human Rights (adopted 22 November 1969, entered into force 18 July 1978) (1970) 9 ILM 673 art 23.
} 
is a reflection of the idea that every person, whether a member of a majority or a minority, has basic rights, including rights to participate in public life. Thus, the authority of a government, elected by a majority, to conduct for the time being the public affairs of the society is a consequence of the exercise of the rights of participation in public life of all citizens, whether they belong to the majority or minority. ${ }^{49}$

This proposition finds support in the Guidance Note on Democracy issued by the UN Secretary General Ban Ki Moon in 2009. ${ }^{50}$ According to the Note: 'democracy is a universal value based on the freely expressed will of people to determine their own political, economic, social and cultural systems and their full participation in all aspects of their lives. ${ }^{51}$

Examining the role that international law could play in guaranteeing a democratic decisionmaking process on GPGs raises the questions of a) the extent to which the international legal system itself is consistent with democratic values; and b) the extent to which international law allows public participation, ie participation of a broad range of actors, in decision-making at the international law level.

\section{The (un)democratic features of international law}

It is submitted that core features of the international legal system are undemocratic, or at least, able to function in an undemocratic way. First, it needs to be borne in mind that classic international law is neutral when it comes to the question of democracy in the context of recognition of States. In this context, emphasis is placed on the objective characteristics of Statehood as these are fleshed out in the 1933 Montevideo Convention ${ }^{52}$ and the question of whether an entity putting forward a claim to Statehood is democratic is not considered. ${ }^{53}$ However, since the end of the Cold War, the nature of a State's internal organisation as a criterion for the recognition of new States has made some headway and the relevant European practice is worth mentioning. In 1991 the (then) European Community adopted a set of Guidelines on the Recognition of New States in Eastern Europe and in the Soviet Union. ${ }^{54}$ The Guidelines recorded the determination of the Community's Member States to 'recognise,

\footnotetext{
${ }^{49}$ Crawford (n 48) 114 (emphasis in the original).

${ }^{50}$ Guidance Note of the Secretary General on Democracy (September 2009) $<$ www.un.org/democracyfund/sites/www.un.org.democracyfund/files/file_attach/UNSG\%20Guidance $\% 20 \mathrm{Not}$ e\%20on\%20Democracy-EN.pdf> accessed 15 August 2017.

51 ibid 2.

52 Montevideo Convention on the Rights and Duties of States (adopted 26 December 1933, entered into force 26 December 1934) 165 LNTS 19.

53 Jan Wouters, Bart De Meester and Cedric Ryngaert, 'Democracy and International Law', Leuven Interdisciplinary Group on International Agreements and Development, Working Paper No 5 (June 2004), 17 $<$ www.law.kuleuven.be/iir/nl/onderzoek/wp/WPLirg5.pdf $>$ accessed on 15 August 2017.

${ }^{54}$ European Community, 'Declaration on the Guidelines on the Recognition of New States in Eastern Europe and in the Soviet Union' (adopted 16 December 1991) (1992) 31 ILM 1485.
} 
subject to the normal standards of international practice and the political realities in each case, those new States which, following the historical changes in the region, have constituted themselves on a democratic basis.' By conditioning recognition on the basis of democratic rule the Guidelines clearly contained considerations of democratic legitimacy that went beyond the traditional criteria for Statehood. At the same time, there is little evidence to suggest that the 'commitment to democracy' as a pre-condition for Statehood has attained the status of customary international law. ${ }^{55}$ Having reviewed the relevant State practice, Murphy concludes: 'In sum, notions of democratic legitimacy are certainly present in contemporary practice concerning recognition of States. However, the evidence of these notions is not uniform, and it derives exclusively from the practice of States that are themselves democratic. ${ }^{56}$

Furthermore, classic international law gives democratic legitimacy short shrift in the context of recognition of governments. Based on the concept of State sovereignty, classic international law is concerned with the regulation of inter-State behaviour and remains neutral towards the democratic origin of new governments. ${ }^{57}$ Writing in 1905 Oppenheim stated that from an international law point of view each State had 'the faculty of adopting any Constitution it likes and of changing such Constitution according to its discretion. ${ }^{58}$ This classic view, which underscores the irrelevance of considerations of democratic pedigree in the context of recognition of governments, is reflected in the Tinoco arbitration. ${ }^{59}$ According to sole arbitrator Taft:

[W]hile [non-recognition] by other nations of a government claiming to be a national personality ... is usually appropriate evidence that it has not attained the independence and control entitling it by international law to be claimed as such, ... when recognition vel non of a government is by such nations determined by inquiry ... into its illegitimacy or irregularity of origin, their non-recognition loses something of evidential weight on this issue with which those applying the rules of international law are alone concerned ... [The United States and Great Britain's] non-recognition ... cannot outweigh the evidence

55 James Crawford, The Creation of States in International Law (2 ${ }^{\text {nd }}$ edn, Clarendon Press 2006) 155; Charlesworth (n 46) 79.

${ }^{56}$ Sean Murphy, 'Democratic Legitimacy and Recognition' in Gregory H Fox and Brad R Roth (eds), Democratic Governance and International Law (CUP 2000) 139.

57 James Crawford, 'Sovereignty as a Legal Value' in James Crawford and Martti Koskenniemi (eds), The Cambridge Companion to International Law (CUP 2012) 132.

${ }^{58}$ Lassa Oppenheim, International Law (1 ${ }^{\text {st }}$ edn, Longman 1905) 403.

${ }^{59}$ Aguilar-Amory and Royal Bank of Canada Claims (United Kingdom v Costa Rica) (Tinoco), (1923) 1 RIAA 369. 
disclosed by this record before me as to the de facto character of Tinoco's government, according to the standard set by international law. ${ }^{60}$

It needs to be noted though that this position has not been followed consistently and that there are some instances where considerations of democratic legitimacy have been taken into account in the recognition of new governments. ${ }^{61}$ However, as is the case concerning recognition of States, the fact that a government is not democratic does not imply that it will be refused recognition. ${ }^{62}$ On the whole, relevant practice shows that in determining whether to recognise another government, States do not consider the non-democratic origin of the government as decisive. ${ }^{63}$

International law has several other features that are in tension with democracy. There is the assumption that the executive of a particular State has plenary power to enter into international commitments - without any reference to the consent of the population of the State. ${ }^{64}$ The relationship between international law and national legal systems may also be seen as undemocratic. From an international legal perspective, national law is not an excuse for failure to live up to international commitments - even if the former is democratically established. ${ }^{65}$

Another undemocratic feature pertains to the almost unlimited power of the government to bind the State at the international level. International law views the authority of the government over the State as 'a continuing entity, no matter how undemocratic the Government. ${ }^{\prime 66}$ In the Tinoco arbitration, the claim that the undemocratic acquisition of power precluded a government from recognition was rejected and it was held that the successor government was bound by all acts of its predecessor irrespective of the latter's illegitimacy, on the grounds that it had retained effective control of the State. ${ }^{67}$

\footnotetext{
60 ibid 381 (emphasis added).

${ }^{61}$ Crawford (n 55) 150. See for example the US practice in relation to the recognition of new governments in the Dominican Republic, Ecuador, Haiti, Cuba, Portugal and the Soviet Union. Murphy (n 52) 140-143. Crawford discusses more recent practice of 'pro-democratic recognition' eg in relation to Fiji, Honduras and Libya but, again, he notes that this practice is not uniform. James Crawford, 'Chance, Order, Change: The Course of International Law' (2013) 365 Recueil des Cours 9, 382.

62 ibid 143.

63 Jean d'Aspremont, 'The Rise and Fall of Democracy Governance in International Law: A Reply to Susan Marks' (2011) 22 EJIL 549, 559-563; Erika de Wet, 'From Free Town to Cairo via Kiev: The Unpredictable Road of Democratic Legitimacy in Governmental Recognition (16 January 2015) <www.asil.org/blogs/freetown-cairo-kiev-unpredictable-road-democratic-legitimacy-governmental-recognition> accessed on 15 August 2015 .

${ }^{64}$ James Crawford, 'Democracy and the Body of International Law' in Fox and Roth (n 56) 96; Charlesworth (n 46) 70. See eg Vienna Convention on the Law of Treaties (adopted 23 May 1969, entered into force 27 January 1980) 115 UNTS 331 (VCLT) art 7.

${ }^{65}$ Crawford (n 61); Charlesworth (n 46) 71. See eg VCLT art 27.

${ }^{66}$ Crawford (n 61) 383.

${ }^{67}$ Tinoco (n 59) 381-382.
} 
The principle of non-intervention enshrined in art 2(7) of the UN Charter can also be viewed as potentially hostile to democracy. Art 2(7) which provides that "nothing contained in the present Charter shall authorize the United Nations to intervene in matters which are essentially within the domestic jurisdiction of any State' illustrates the persistent focus of classic international law on the carapace of the State and not on its internal structure by shielding State sovereignty from foreign intervention - irrespective of how undemocratic the internal structure might be. ${ }^{68}$

Scholarly attempts to pierce sovereignty's statist veil and to replace it with notions of 'popular sovereignty' (whereby true sovereignty is vested in the people of the State) ${ }^{69}$ in order to buttress the argument that international law sanctions 'pro-democratic' interventions ${ }^{70}$ fall short of convincing as they rest on slim evidentiary grounds. The US invasion in Panama, which was justified, inter alia, as an action in support of democracy, ${ }^{71}$ was vociferously condemned by the UN General Assembly as 'a flagrant violation of international law and of the independence, sovereignty and territorial integrity of States.' 72 As far as the Grenada invasion is concerned, the US did not invoke the restoration of democracy as a justification ${ }^{73}$ and it was also condemned by the UN General Assembly. ${ }^{74}$ Similarly, a unilateral right of prodemocratic intervention was not raised in other actions directed against undemocratic regimes including Tanzania's action against Uganda in 1979; 75 Vietnam's invasion of Cambodia in $1979 ;{ }^{76}$ and the invasion of Iraq in $2003 .{ }^{77}$ Equally, there is little evidence to support the view that a multilateral right to intervene in the name of democracy has emerged. The 1994 Haiti

\footnotetext{
${ }^{68}$ Wouters, De Meester and Ryngaert (n 53) 25.

${ }^{69}$ W Michael Reisman, 'Sovereignty and Human Rights in Contemporary International Law' in Fox and Roth (eds) (n 56) 240. See also generally Anthony D'Amato, 'The Invasion of Panama Was a Lawful Response to Tyranny' (1990) 84 AJIL 516.

${ }^{70}$ Reisman (n 69) 245; D'Amato (n 69) 519; Gregory H Fox and Brad R Roth, 'Democracy and International Law' (2001) 27 Review of International Studies 327, 336.

${ }^{71}$ Michael Byers and Simon Chesterman, "You, The People": Pro-Democratic Intervention in International Law' in Fox and Roth (n 56) 275.

${ }^{72}$ UN General Assembly res 44/240 (29 December 1989) UN Doc A/RES/44/240.

${ }^{73}$ Byers and Chesterman (n 71) 272-273.

${ }^{74}$ UN General Assembly res 38/7 (2 November 1983) UN Doc A/RES/38/7.

75 James Crawford, 'Self-Determination outside the Colonial Context' in W J Allan Macartney (ed), SelfDetermination in the Commonwealth (Aberdeen University Press 1988) 10.

${ }^{76}$ Gary Klintworth, Vietnam's Intervention in Cambodia (AGPS 1989). See also the statement made by the French delegate during the relevant Security Council debate: 'The notion that because a regime is detestable foreign intervention is justified and forcible overthrow is legitimate is extremely dangerous. That could ultimately jeopardize the very maintenance of international law and order and make the continued existence of various regimes dependent on the judgment of their neighbors.' as quoted in Byers and Chesterman (n 71) 280.

${ }^{77}$ Charlesworth (n 46) 89. See also Wolff Heintschel von Heinegg, 'Iraq, Invasion of' in Rüdiger Wolfrum (ed), Max Planck Encyclopedia of Public International Law, Oxford University Press, October 2015 <opil.ouplaw.com/view/10.1093/law:epil/9780199231690/law-9780199231690-e1820> accessed 15 August 2017.
} 
intervention to reinstate the legitimately elected President Aristide was based on a Security Council resolution ${ }^{78}$ adopted in response to an express request for UN action by the Aristide government - which had, thus, consented to the intervention. ${ }^{79}$

In a similar vein, arguments in favour of pro-democratic intervention have a tenuous foundation in international judicial practice. In the Corfu Channel case, the British argument to the effect that the UK had a right to intervene in Albanian waters to remove mines was rejected because of the 'serious abuses' that such a right might give rise to. ${ }^{80}$ In the Nicaragua case, the ICJ rejected the existence of a rule that allowed intervention 'by one State against another on the ground that the latter has opted for some particular ideology or political system. ${ }^{81}$

The above analysis shows that democracy is far from being an established element in the international legal order and that core features of international law remain undemocratic. Crawford has put the matter most succinctly: 'The international rule of law does not encapsulate substantive values such as democracy, and the extent to which it serves to enable democracy or accountability remains an open question. ${ }^{82}$

\section{International law and the question of public participation}

The democratic deficit of the international legal system and the difficulties of extrapolating democratic theories to the international level have prompted part of the scholarship 'to focus on one particular aspect of democracy, namely public participation. ${ }^{93}$ Calls to explore the role international law could play in the democratisation process underlying the definition of GPGs have proceeded along similar lines by specifically focusing on the participation gap in the decision-making processes on GPGs. ${ }^{84}$ From this vantage point, the question then becomes one of exploring how international law could 'contribute to rendering decisions on GPGs more adjusted to the preferences of world citizens. ${ }^{95}$

However, when it comes to issues of participation, the State-centric nature of classic international law leaves much to be desired. While it is true that the ICJ's Advisory Opinion in Reparations for Injuries constituted a breaking point where international legal personality

\footnotetext{
${ }^{78}$ UN Security Council res 940 (1994).

${ }^{79}$ Byers and Chesterman (n 71) 287; Wouters, De Meester and Ryngaert (n 53) 30. As far as pro-democratic intervention authorized by regional organisations is concerned, practice remains mixed on this score. Crawford (n 61) 388.

${ }^{80}$ Corfu Channel Case (UK v Albania) (Merits) [1949] ICJ Rep 4, 35.

${ }^{81}$ Case concerning Military and Paramilitary Activities in and against Nicaragua (Nicaragua $v$ United States of America) (Merits) [1986] ICJ Rep 14, 123.

${ }^{82}$ Crawford (n 61) 401.

${ }^{83}$ Bodansky (n 21) 617.

${ }^{84}$ Cogolati, Hamid and Vanstappen (n 37) 21-22.

85 ibid 21.
} 
(namely the ability to possess rights and obligations) and the capacity to act (namely legal capacity, including procedural and law-making capacity) came to be severed from each other, ${ }^{86}$ the latter still remains the prerogative of States and State-empowered bodies. ${ }^{87}$ In LaGrand, Avena and Diallo the Court expressly acknowledged that non-State actors may have rights deriving directly from international law, while highlighting, at the same time, that the procedural capacity to pursue these rights remains with the State of nationality. ${ }^{88}$ Furthermore, the Court has been, thus far at least, quite reluctant to acknowledge the law-making capacity of entities other than States - as evidenced by its rulings in the Anglo-Iranian Oil and Land and Maritime Boundary cases. ${ }^{89}$

The reluctance towards conceding law-making capacity to entities other than States has not been affected by the proliferation of State contracts in the context of international investment law. ${ }^{90}$ The reasoning of sole arbitrator Dupuy in Texaco/Calasiatic $v$ Libya to the effect that 'a contract between a State and a private person falls within the international legal order ${ }^{91}$ has been fiercely criticised in the literature and not followed in practice. ${ }^{92}$ On the contrary, more recent awards have emphasised the difference between international

\footnotetext{
${ }^{86}$ Reparations for Injuries Suffered in the Service of the United Nations (Advisory Opinion) [1949] ICJ Rep 174, 177-179. On the distinction between legal personality and legal capacity, see Hermann Mosler, 'Subjects of International Law' in Rudolf Bernhardt (ed), Encyclopedia of Public International Law, vol VII (Elsevier Science Publishers 1984) 443; Ilias Plakokefalos, 'Treaties and Individuals: Of Beneficiaries, Duty-Bearers, Users and Participants' in Christian Tams, Antonios Tzanakopoulos and Andreas Zimmermann (eds), Research Handbook on the Law of Treaties (Edward Elgar 2014) 630; Eva Kassoti, 'The Normative Status of Unilateral Ad Hoc Commitments by Non-State Armed Actors in Internal Armed Conflicts: International Legal Personality and Lawmaking Capacity Distinguished' (2016) 21 JCSL 1, 12-21.

${ }^{87}$ Crawford (n 61) 200-211. State-empowered bodies are bodies created by States and 'granted authority to make decisions or take actions' and thus, their law-making capacity is derived from State consent. International organizations are the prime examples of State-empowered bodies. Conversely, non-State actors is a category that is primarily defined by reference to what it is not; these entities are neither States, nor State-empowered bodies. This group encompasses individuals, NGOs, corporations and other entities that have no widely recognized lawmaking capacity in international law. See Anthea Roberts and Sandesh Sivakumaran, 'Lawmaking by Nonstate Actors: Engaging Armed Groups in the Creation of International Humanitarian Law' (2012) 37 Yale J Intl L 107, 116. See also Sandesh Sivakumaran, 'Beyond State and Non-State Actors: The Role of State-Empowered Entities in the Making and Shaping of International Law' (2017) 55 Col J Trans L 343, 351.

${ }^{88}$ LaGrand Case (Germany v United States of America) (Judgment) [2001] ICJ Rep 466, para 77; Case concerning Avena and Other Mexican Nationals (Mexico v United States of America) (Judgment) [2004] ICJ Rep 12, para 40; Ahmadou Sadio Diallo Case (Republic of Guinea v Democratic Republic of the Congo) (merits) [2010] ICJ Rep 639, para 164.

89 Anglo-Iranian Oil Co Case (United Kingdom v Iran) (Preliminary Objections) [1952] ICJ Rep 93, 112-113; Case concerning the Land and Maritime Boundary between Cameroon and Nigeria (Cameroon v Nigeria; Equatorial Guinea intervening) (Judgment) [2002] ICJ Rep 303, para 205.

90 See generally Markos Karavias, 'Treaty Law and Multinational Enterprises: More than Internationalized Contracts?,' in Tams, Tzanakopoulos and Zimmermann (eds) (n 86) 597.

${ }^{91}$ Texaco Overseas Petroleum Company and California Asiatic Oil Company $v$ The Government of the Libyan Arab Republic (1977) 53 ILR 422, para 47.

92 Christopher Greenwood, 'State Contracts in International Law - The Libyan Oil Arbitrations' (1982) 53 BYIL 27, 49; Robert B Von Mehren and Nicholas Kourides, 'International Arbitrations between States and Foreign Private Parties: The Libyan Nationalization Cases’ (1981) 75 AJIL 476, 511-512.
} 
agreements (concluded between States and directly governed by international law) and State contracts (concluded between a State and a private party and regulated mainly by municipal law and partially by international law by way of analogy). ${ }^{93}$ Thus, according to mainstream legal thinking, although non-State actors have - to a certain extent - managed to carve out a legal space for themselves, States are still considered the predominant actors in international law and the gatekeepers of the international legal system. ${ }^{94}$

Some positivists acknowledge that the changes on the ground of international practice call for a change in the way we conceptualise international law. ${ }^{95}$ At the same time, according to this school of thought, the participation problem escapes the academic realm and can only be meaningfully solved if the key players of the system are willing to address it. As Zemanek stresses, States 'are the only ones that could initiate a modification of or an addition to the existing international law.' 96 The above analysis has shown that core tenets of international law are, at a minimum, able to function in an undemocratic way and that mainstream legal positivism is not well-suited to addressing the participation gap in the definition of GPGs. Against this background, the remainder of the article will examine two alternative theoretical frameworks, which attempt to bridge the participation gap, namely global administrative law and global constitutionalism.

\section{GLOBAL ADMINISTRATIVE LAW}

Accountability in international law, however described or perceived, is premised on the existence of a clear yardstick against which conduct can be tested. As Klabbers observes: "Classic international law has understood this very well: it is clear that State responsibility may only be incurred for ... acts that amount to a violation of ... an international legal obligation resting upon an actor." 97 The key point here is that, according to the traditional framework of international legal accountability, responsibility is related to a violation of the law by a recognised subject of the international legal system. As it has been noted above both what counts as 'law' and who counts as a 'subject' of international law are seen, in the

\footnotetext{
${ }^{93}$ Roland Portland, Legal Personality in International Law (CUP 2013) 124. See for example CAA and Vivendi Universal v Argentina, Case No ARB/97/3 (2002) 6 ICSID Rep 340, paras 96-98; SGS Société Générale de Surveillance $S A v$ Republic of the Philippines, Case No ARB/02/6 (2004) 8 ICSID Reports 515, paras 126-128. ${ }^{94}$ Mosler (n 86) 443-444. Roberts and Sivakumaran (n 87) 113; Cedric Ryngaert, 'Non-State Actors: Carving out a Space in a State-Centred International Legal System’ (2016) 63 NILR 1, 10-11.

95 Jean d'Aspremont, Epistemic Forces in International Law: Foundational Doctrines and Techniques of International Legal Argumentation (Edward Elgar 2015) 126-129.

${ }^{96}$ Karl Zemanek, 'International Law Needs Development. But Where to?' in Ulrich Fastenrath (ed), From Bilateralism to Community Interest: Essays in Honour of Judge Brunno Simma, (OUP 2011) 797.

${ }^{97}$ Jan Klabbers, 'International Courts and Informal International Law' in Joost Pauwelyn, Ramses A Wessel and Jan Wouters (eds), Informal International Lawmaking (OUP 2012) 219.
} 
traditional understanding, as being contingent upon State consent. The inability of this traditional framework to capture new actors and forms of exercise of regulatory power underpins the global administrative law project, ${ }^{98}$ whose main focus lies on addressing the accountability deficit in global governance. According to Kingsbury, global administrative law can be understood as 'the legal mechanisms, principles and practices, along with supporting social understandings, that promote or otherwise affect the accountability of global administrative bodies. ${ }^{99}$ In order to ascertain what promotes accountability, authors of this persuasion have recourse to a number of informal criteria such as transparency, consultation, participation, reasoned decisions and review mechanisms. ${ }^{100}$ The aggregate result of the existence of these informal benchmarks is that they enhance 'publicness', namely the idea that law is shaped by the whole society, an element that Kingsbury considers fundamental in the concept of law under modern democratic conditions. ${ }^{101}$ The appeal of the global administrative law project lies in the ambition of its founders to ground it in 'a revived version of ius gentium that could encompass norms emerging from a wide variety of actors and in very diverse settings. ${ }^{102}$ This ambition resonates with modern worries regarding the accountability of nonState entities engaged in normative and standard-setting activities.

According to this school of thought, the real addressees of modern regulatory regimes 'are now increasingly the same as in domestic law: namely, individuals ... and collective entities like corporations and, in some cases, NGOs. ${ }^{103}$ Since the circle of subjects of global regulation has widened to incorporate a number of entities alongside States, advocates of global administrative law argue that all those affected by decisions of global regulatory mechanisms should be involved in making them. ${ }^{104}$ However, the project's founders have readily acknowledged its shortcomings when it comes to implementing broader participatory mechanisms. Kingsbury, Krisch and Stewart concede that, although democratic legitimacy is one of the main normative conceptions underpinning global administrative law, the project is faced with 'serious problems of definition and implementation.' ${ }^{105}$ They acknowledge that the

\footnotetext{
98 Benedict Kingsbury, Nico Krisch and Richard B Stewart, 'The Emergence of Global Administrative Law' (2005) 68 Law and Contemporary Problems 15, 16.

${ }^{99}$ Benedict Kingsbury, 'The Concept of 'Law' in Global Administrative Law' (2009) 20 EJIL 23, 25.

100 ibid.

101 ibid 31.

102 Kingsbury, Krisch and Stewart (n 98) 29.

103 ibid 23-24.

104 ibid 23-25.

105 ibid 48.
} 
global administrative law's strong commitment to inclusiveness would leave much room for disagreement about whose acts to count for the emergence of a new rule. ${ }^{106}$

More fundamentally, global administrative law's primary focus on accountability means that the project lacks ambition when it comes to the question of broadening decisionmaking processes. Indeed, an early framing of global administrative law bracketed the question of democracy, in the sense of participation of affected groups in decision-making processes, as too ambitious an idea for global administration. ${ }^{107}$ However, this bracketing seems normatively dubious to many. According to Krisch, an excessive focus on accountability implies losing sight of the need of public participation in rule-making. ${ }^{108}$ As Harlow observes, overemphasising accountability mechanisms may lead to a 'juridification' of global governance where considerations of procedure would prevail over considerations of broad participation and democratic legitimacy. ${ }^{109}$ Turning to the issue at hand, the limited ambition of global administrative law implies that the project would be of limited assistance in integrating participatory principles in the definition of GPGs. The same conclusion has been reached by Schaffer who observes that 'the global administrative law approach is rather technocratic and thus lacks ambition regarding large scale questions of governance requiring political decision-making for the production of global public goods. 110

\section{E. GLOBAL CONSTITUTIONALISM}

While different definitions of the concept have been put forward, ${ }^{111}$ it is generally conceded that global constitutionalism:

[I]s an academic and political agenda that identifies and advocates for the application of constitutionalist principles, such as the rule of law, checks and balances, human rights protection, and possibly democracy, in the international legal sphere in order to improve the effectiveness and fairness of the international legal order. ${ }^{12}$

\footnotetext{
106 ibid 30.

107 ibid 50.

108 Nico Krisch, 'Global Administrative Law and the Constitutional Ambition', LSE Law, Society and Economy Working Papers 10/2009, (October 2009) 15-17, $<$ www.lse.ac.uk/collections/law/wps/WPS2009-10_Krisch.pdf> accessed 15 August 2017.

${ }^{109}$ Carol Harlow, 'Global Administrative Law: The Quest for Principles and Values' (2006) 17 EJIL 187, $213-$ 214.

${ }^{110}$ Shaffer (n 22) 689. See also Cogolati, Hamid and Vanstappen (n 37) 25-26.

${ }^{111}$ For an overview see Christine Schwöbel, and Global Constitutionalism in International Legal Perspective, (Martinus Nijhoff 2011) 11-50. For definitions of the terms 'constitutionalism' and 'constitutionlaization' see Martin Loughlin, 'What is Constitutionalisation?' in Petra Dobner and Martin Loughlin (eds), The Twilight of Constitutionalism (OUP 2010) 47.

${ }^{112}$ Anne Peters and Klaus Armingeon, 'Global Constitutionalism from an Interdisciplinary Perspective' (2009) 16 Ind J Global L Studies 385, 389.
} 
It is noteworthy that constitutionalism has not been touted as a distinct legal theory. Rather, it has been put forward as a distinct doctrinal approach within the broader positivist camp - as an effort to construe international law in terms borrowed from domestic constitutionalism with a view to enhancing international law's legitimacy. ${ }^{113}$ In this sense, instead of advocating a radical break with positivism, the constitutionalist argument in international law is of an essentially political nature; it is an argument in favour of the consolidation of democratic values such as the rule of law, democracy and the protection of human rights in international law. ${ }^{114}$ As von Bogdandy stresses, adherents of global constitutionalism strive to attain the vision of a 'global legal community that frames and directs political power in light of common values and a common good.' 115

Global constitutionalism arose 'as a knee-jerk response to come to terms with the existential anxiety of fragmentation.' ${ }^{116}$ Fragmentation, namely the splitting up of law into highly specialised regimes such as 'human rights law', 'trade law' and 'environmental law' that are relative autonomous from each other, as well as from general international law, carries the risk of the emergence of conflicting norms for the solution of the same legal issue. ${ }^{117}$ Constitutionalism taps into modern worries regarding fragmentation by emphasising the existence of a normative hierarchy in international law. Proponents of constitutionalism view fundamental norms, like jus cogens and erga omnes obligations, as hierarchically superior 'constitutional' law ${ }^{118}$ and for some the UN Charter is the constitution of the international community itself. ${ }^{119}$ The project owes much of its appeal to the promise of unity, hierarchy, legitimacy and coherence that the very term 'constitution' implies. ${ }^{120}$

\footnotetext{
${ }^{113}$ Richard Collins, 'Constitutionalism as Liberal-Juridical Consciousness: Echoes from International Law's Past' (2009) 22 LJIL 251.

${ }^{114}$ Steven Wheatley, The Democratic Legitimacy of International Law (Hart Publishing 2010) 190.

115 Armin von Bogdandy, 'Constitutionalism in International Law: Comment on a Proposal from Germany' (2006) 47 Harv Intl L J 223, 223.

116 Jan Klabbers, 'Constitutionalism Lite' (2004) 1 IOLR 31, 49.

${ }^{117}$ International Law Commission (ILC), 'Fragmentation of International Law: Difficulties Arising from the Diversification and Expansion of International Law - Report of the Study Group of the International Law Commission' (13 April 2006) UN Doc A/CN.4/L.682 (finalised by Martti Koskenniemi) paras 8, 13 $<$ legal.un.org/ilc/documentation/english/a_cn4_1682.pdf> accessed 15 August 2017.

118 Erika de Wet, 'The International Constitutional Order' (2006) 55 ICLQ 51, 57; Bardo Fassbender, 'The Meaning of International Constitutional Law' in Nicholas Tsagourias (ed), Transnational Constitutionalism: International and European Models (CUP 2007) 316.

119 See generally Bardo Fassbender, The United Nations Charter as the Constitution of the International Community (Martinus Nijhoff 2009); Pierre-Marie Dupuy, 'The Constitutional Dimension of the Charter of the United Nations Revisited' (1997) 1 Max Planck UNYB 1, 3.

${ }^{120}$ According to Allott: 'International constitutional law is what some older writers called the 'necessary' law of nations. It contains the structural legal relations which are intrinsic to the co-existence of all kinds of subordinate societies. It confers on artificial legal persons, including the state-societies, the capacity to act as parties to international legal relations ... The geographical and material distribution of constitutional authority among subordinate legal systems cannot be finally determined by those legal systems themselves, but only by a
} 
For many, global constitutionalism holds greater promise for integrating participatory principles in the definition of GPGs. ${ }^{121}$ According to Petersmann:

As multilevel governance of interdependent international public goods has become the most challenging task in the twenty-first century - the current undersupply of international public goods requires embedding [international economic law] into stronger constitutional, cosmopolitan and democratically justifiable foundations. ${ }^{122}$

Although proponents of global constitutionalism concede there is still much ground to cover, ${ }^{123}$ it has been asserted that this intellectual framework offers two important insights on how international law could be conducive to filling the participation gap in the definition of GPGs.

\section{Community interest}

First, global constitutionalism promotes the 'concept of community interest'; the emergence of jus cogens norms, erga omnes obligations and the prevalence of Member States' obligations under the UN Charter over any other conflicting obligations in accordance with Art 103 UN Charter are all considered 'manifestations in positive international law of the concern for the protection of community interests, and implicitly, GPGs.' ${ }^{124}$ It is argued that such principles of international law contribute to the vertical integration of the international legal order 'by recognising public goods which transcend state interests as global challenges'. ${ }^{125}$

However, this proposition is not free of contradictions. First, it is not entirely clear how the promotion of the 'concept of community interest' is tangibly conducive to filling the participation gap in the definition of GPGs. Even if, arguendo, one accepts that, indeed, all the aforementioned principles of international law are manifestations of the international law concern for the protection of community interests, it is difficult to see how this concern could (in and of itself) help broaden decision-making processes pertaining to GPGs.

Furthermore, even if one merely accepts this proposition as empirical evidence in favour of constitutionalism, namely as evidence of a paradigm shift in international law from

superordinate legal system, namely international constitutional law. ... International constitutional law determines the legal relationship of the subordinate public realms.' Philip Allott, 'The Concept of International Law' in Michael Byers (ed), The Role of Law in International Politics: Essays in International Relations and International Law (OUP 2001) 75.

121 Cogolati, Hamid and Vanstappen (n 37) 26-27. See also Mattias Kumm, 'The Cosmopolitan Turn in Constitutionalism: An Integrated Conception of Public Law’ (2013) 20 Ind J Global L Studies 605, 611; Daniel Augenstein, 'To Whom It May Concern: International Human Rights Law and Global Public Goods' (2016) 23 Ind. J Global L Studies 225, 231.

122 Ernst-Ulrich Petersmann, International Economic Law in the 21 $1^{\text {st }}$ Century: Constitutional Pluralism and Multilevel Governance of Interdependent Public Goods (Hart Publishing 2012) 25.

${ }^{123}$ Shaffer (n 22) 686.

124 Cogolati, Hamid and Vanstappen (n 37) 28.

125 ibid (emphasis in the original). 
egotistical States to community interests in the form of GPGs, it is still difficult to identify with precision a common set of constitutional principles. ${ }^{126}$ Apart from a widely agreed minimum including the prohibition of aggression, slavery and slave trade, genocide, racial discrimination apartheid and torture, as well as the basic rules of international humanitarian law applicable in armed conflict, and the right to self-determination, there is much disagreement regarding the exact scope of the concept of jus cogens norms. ${ }^{127}$

Finally, the claim that jus cogens norms, erga omnes obligations and the effect of Art 103 of the UN Charter demonstrate that a normative hierarchy exists in international law is contested. Apprehending jus cogens as hierarchically superior 'constitutional' norms is deeply problematic as Kolb has pointed out. ${ }^{128}$ According to him, jus cogens in international law functions in a similar way as in domestic law, namely 'as a legal technique whereby the unity of a legal regime is maintained ratione personae by denying the application of the rule lex specialis derogat generali in order to satisfy a collectively held interest in the equal application of a legal regime to all parties. ${ }^{129}$ In other words, jus cogens is a tool employed to keep a legal regime intact by giving precedence to certain general rules over special ones - in reversal of the ordinary lex specialis rule. In this sense, the concept is one pertaining to the relationship between general and more special rules, rather than one pertaining to questions of hierarchy. ${ }^{130}$ Conceptualising jus cogens as a rule of hierarchy is problematic to the extent that the lex superior rule does not necessarily imply the nullity of the inferior rule; it merely means that the superior rule enjoys precedence. ${ }^{131}$ This however cannot be reconciled with the 'voidnesslogic' of jus cogens. ${ }^{132}$ Furthermore, the hierarchy argument is not convincing from the point of view of practice. Understanding jus cogens norms as hierarchically superior norms generates the expectation that they will always prevail over other norms of international law. ${ }^{133}$

126 Katja S Ziegler, 'International Law and EU Law: Between Asymmetric Constitutionalisation and Fragmentation' in Alexander Orakhelashvili (ed), Research Handbook on the Theory and History of International Law (Edward Elgar 2011) 322.

${ }^{127}$ ILC (n 117) para 33. See also James Crawford, Brownlie's Principles of Public International Law ( $8^{\text {th }}$ edn, OUP 2012) 596.

${ }_{128}$ Robert Kolb, Peremptory International Law - Jus Cogens: A General Inventory (Hart Publishing 2015). See also Michel Virally, 'Réflexions sur le Jus Cogens' (1966) 12 ADFI 5, 18.

${ }^{129} \mathrm{Kolb}$ (n 128) 3. Thus, according to Kolb, the concept of jus cogens both in international law and in municipal law essentially serves the same function. As Kolb explains, in some cases, 'there is an interest, imposed by the legislator or ruled by tribunals, in keeping a legal regime entire and binding on all subjects by allowing no contracting out... These legal norms are thus said to be "non-derogable", that is, not replaceable by special legal regimes applicable as leges speciales between some parties. This is the proper domain of jus cogens.': ibid.

130 ibid. See also Jean d' Aspremont, 'The Foundations of the International Legal Order' 2009, 29$31<$ dare.uva.n1/document/2/89866> accessed 15 August 2017.

${ }^{131}$ D’Aspremont (n 130) 58.

${ }^{132}$ See eg VCLT art 53, which provides that '[a] treaty is void if, at the time of its conclusion, it conflicts with a peremptory norm of general international law.'

${ }^{133}$ D'Aspremont (n 130) 59. 
However, as the ICJ found in the Jurisdictional Immunities case, even if certain human rights are considered jus cogens this does not mean that jurisdictional immunities do not apply any longer. ${ }^{134}$ On this basis, the better view is to conceptualise jus cogens as a functional device to avoid the fragmentation of the international legal order through non-derogability rather than as hierarchically superior norms. ${ }^{135}$

The constitutionalist claim that the concept of erga omnes obligations is a manifestation of the existence of a normative hierarchy in international law has also been belied. ${ }^{136}$ According to the ILC Study Group on fragmentation of international law:

A norm which is creative of obligations erga omnes is owed to the 'international community as a whole' and all States - irrespective of their particular interest in the matter are entitled to invoke State responsibility in case of breach. The erga omnes nature of an obligation, however, indicates no clear superiority of that obligation over other obligations. Although in practice norms recognised as having an erga omnes validity set up undoubtedly important obligations, this importance does not translate into hierarchical superiority $[\ldots]^{137}$

Similarly it is difficult to see Art 103 of the UN Charter as establishing a system of hierarchy of norms. Art 103 can be explained as a conflict rule regulating the relationship between different treaty regimes - without having to have recourse to the concept of normative hierarchy. ${ }^{138}$ The rule enshrined therein deals with a problem not infrequently encountered in practice: at a certain moment, a State may find itself bound by conflicting treaty obligations owed to different partners. ${ }^{139}$ In this scenario, States are free to choose which obligation to perform, while at the same time accepting responsibility for non-performance towards the parties of the other agreement. Art 103 'pre-empts the choice' by giving precedence to obligations arising under the Charter. ${ }^{140}$ The proposition that Art 103 of the UN Charter is a rule of precedence and not a manifestation of a normative hierarchy in international law is

\footnotetext{
${ }^{134}$ Case concerning Jurisdictional Immunities of the State (Germany v Italy Greece intervening) (Judgment) [2012] ICJ Rep 99, paras 92-97. See also Al-Adsani v the United Kingdom, (2001) 123 ILR 32, 41-43, 50-51.

${ }^{135}$ Kolb (n 128) 57-62.

${ }^{136}$ Jure Vidmar, 'Norm Conflicts and Hierarchy in International Law: Towards a Vertical International Legal System?' in Erika de Wet and Jure Vidmar (eds), Hierarchy in International Law: The Place of Human Rights (OUP 2012) 25.

${ }^{137}$ ILC (n 117) para 380.

${ }^{138}$ Andreas Paulus, 'Jus Cogens in a Time of Hegemony and Fragmentation' (2007) 74 Nordic JIL 297, 317; Vidmar (n 135) 19.

${ }^{139}$ Karl Zemanek, 'The Metamorphosis of Jus Cogens: From an Institution of Treaty Law to the Bedrock of the International Legal Order' in Enzo Cannizzaro (ed), The Law of Treaties Beyond the Vienna Convention (OUP 2011) 391.

140 ibid.
} 
confirmed by the ILC which stated that the Article should be seen 'as a means for securing that Charter obligations can be performed effectively and not as abolishing other treaty regimes however incidental the conflict might be.' 141

\section{The role of non-State actors}

Secondly, it has been claimed that a further attribute of viewing the question of the definition of GPGs through the lens of global constitutionalism is the latter's approach to the question of non-State actors and their participation in international law-making. ${ }^{142}$ More specifically, the argument is that Peters' version of global constitutionalism can be conducive to filling the participation-gap in the definition of GPGs to the extent that it advances a vision of the international community 'that is more constitutionalised and, therefore, more involved in the definition of GPGs.' ${ }^{143}$ In order to assess the merits of this argument, a brief excursus into Peters' strand of global constitutionalism is called for.

Peters' version of constitutionalism stays close to mainstream legal thinking ${ }^{144}$ when it comes to the question of actor informality. Thus, while Peters acknowledges that constitutionalist considerations dictate that the individual is the ultimate unit of legal concern, ${ }^{145}$ she cautions against abolishing the distinction between legal subjects and social actors, that may indirectly influence international law-making processes but which are devoid of legal personality. ${ }^{146}$ According to Peters, abolishing the dichotomy between formal and informal participation in the law-making process would undermine stability and predictability in international relations. ${ }^{147}$ If all types of activities, such as lobbying and making policy statements, were considered as 'law' then the distinction between law and non-law would collapse, thereby undermining legal certainty - something that would run counter to constitutionalist aspirations. ${ }^{148}$ On this basis, Peters concludes that 'it is, from a constitutionalist perspective, for reasons of legal clarity, preferable to insist on the formal

\footnotetext{
${ }^{141}$ ILC (n 117) para 335.

142 Cogolati, Hamid and Vanstappen (n 37 ) 28.

143 ibid 29 and (n 117).

${ }^{144}$ For an exposition of how different strands of constitutionalism have tackled the phenomenon of informal lawmaking by non-State actors, see generally Eva Kassoti, 'The Constitutionalization of International Law and the Challenge of Non-State Actors' (2017) 11 ICLJ 177.

${ }^{145}$ Anne Peters, 'Membership in the Global Constitutional Community' in Jan Klabbers, Anne Peters and Geir Ulfstein (eds), The Constitutionalization of International Law (OUP 2009) 158. See also Hersch Lauterpacht, The Grotian Tradition in International Law (1946) 23 BYIL 1, 27 and more generally Theodor Meron, The Humanization of International Law (Martinus Nijhoff 2006).

146 Peters (n 145) 156.

147 ibid.

148 ibid.
} 
distinction between those actors that vote and those that merely have a voice in international law-making.' 149

Peters buttresses her argument with reference to the legitimacy and accountability deficits of de facto influential actors such as NGOs. From a constitutionalist vantage point, acknowledging a law-creating role for NGOs would be potentially illegitimate, as they are not necessarily democratically organised: elections are infrequent within such bodies. ${ }^{150}$ As Tomuschat stresses, since NGOs are the product of 'societal freedom, they lack the kind of legitimacy which a government emerging from free democratic elections may boast of.' ${ }^{\text {'151 }}$ Furthermore, NGOs are not accountable to the people they are supposed to represent. ${ }^{152}$ Although NGOs often make broad claims to represent certain groups of people, their 'beneficiaries' are not in a position to question their actions. ${ }^{153}$ Thus, NGOs cannot be considered, from a constitutionalist perspective, as the true voice of the peoples they are allegedly representing. ${ }^{154}$

At the same time, this strand of constitutionalism acknowledges that the indirect involvement of non-State actors in international law-making can enhance the legitimacy of global governance. ${ }^{155}$ Despite their shortcomings, NGOs, as non-governmental entities, introduce an independent outlook into global affairs and they help put pressure on States to fulfil their international obligations. ${ }^{156}$ NGOs have a well-documented history of identifying and lobbying for the increased protection of GPGs; the landmines campaign, debt relief, international certification of the diamond trade and access to medicine are good illustrations. ${ }^{157}$ In this light, Peters advocates in favour of broadening, structuring and streamlining the role of NGOs in international law-making processes. ${ }^{158}$ This can be done by formalising and harmonising the relevant selection and accreditation procedures and by rendering financial

\footnotetext{
149 ibid 199.

150 ibid 236. See also Daniel Thürer, 'The Emergence of Non-Governmental Organizations and Transnational Enterprises in International Law and the Changing Role of the State' in Andrea Bianchi (ed), Non-State Actors and International Law (Ashgate 2009) 46.

${ }^{151}$ Christian Tomuschat, 'International Law: Ensuring the Survival of Mankind on the Eve of a New Century' (1999) 281 Recueil des Cours 9, 155.

${ }^{152}$ See generally Hugo Slim, 'By What Authority? The Legitimacy and Accountability of Non-Governmental Organisations' (2002) <www.gdrc.org/ngo/accountability/by-what-authority.html> accessed 15 August 2017.

153 Peters (n 145) 237.

154 Tomuschat (n 151) 155.

155 Peters (n 145) 359.

156 Thürer (n 150) 46.

${ }^{157}$ Michael Edwards, Simon Zadek, 'Governing the Provision of Global Public Goods: The Role and Legitimacy of Nonstate Actors' in Kaul and others (n 2) 203. Kyle Grayson, 'Human Security in the Global Era' in Daniel Drache (ed), The Market or the Public Domain? Global Governance and the Asymmetry of Power (Routledge 2001) 241.

158 Peters (n 145) 239.
} 
assistance and technical support to weaker civil society actors, in order to guarantee inclusiveness and broad participation. ${ }^{159}$

It is difficult to see how the distinction between formal and informal participation brings anything new to the table. Indeed, traditional legal thinking is anything but unfamiliar with the conceptual distinction between direct and indirect participation in international law-making. Even avowed positivists, such as Brownlie, have recognised that informal prescriptions issued by actors other than States may have a 'catalytic effect' in shaping the law. ${ }^{160}$ More recently, the ILC's Special Rapporteur on the topic of identification of customary international law, Michael Wood, expressed a similar view. Wood opined that actors other than States and international organisations may play an indirect role in the formation of customary law insofar as their conduct may prompt or record State practice and the practice of international organisations. ${ }^{161}$

NGOs have a well-documented history of involvement in treaty-making for over 200 years. ${ }^{162}$ Non-State entities are also a catalyst for the formation of customary international law. As Judge Van den Wyngaert stressed in her Dissenting Opinion in the Arrest Warrant Case: '[T]he opinion of civil society ... cannot be completely discounted in the formation of customary international law today. ${ }^{163}$ A classic example here is the contribution of the International Law Association to the crystallisation of the principle of equitable utilisation as a rule of customary law in the context of international water law. ${ }^{164}$

The above examples illustrate that traditional international legal thinking has envisaged law-creation as a broad concept within which the normative significance of the stages preceding the threshold of legality can be captured. At the heart of this approach lies the recognition that while a number of actors may influence the formation of law, they cannot enter the formal law-making process in an unmediated fashion - thereby allowing us to straddle

\footnotetext{
159 ibid 240.

${ }^{160}$ Ian Brownlie, 'Lex Lata and Lex Ferenda' in Antonio Cassese and Joseph Weiler (eds), Change and Stability in International Law-Making (Walter de Gruyter 1998) 70. See also Maurice Mendelson, 'The Formation of Customary International Law' (1998) 272 Recueil des Cours 155, 203.

${ }^{161}$ ILC, 'Report of the International Law Commission on the Work of its 67th session' (4 May-5 June, 6 July7 August 2015) UN Doc A/70/10, 47, para 99.

${ }^{162}$ See generally Steve Charnovitz, 'Two Centuries of Participation: NGOs and International Governance' (19961997) 18 Mich J Intl L 183.

${ }^{163}$ Dissenting Opinion of ad hoc Judge Van den Wyngaert in Arrest Warrant of 11 April 2000 (Democratic Republic of the Congo v Belgium) (Judgment) [2002] ICJ Rep 137, 155 (emphasis in the original).

${ }^{164}$ See generally Charles B Bourne, 'The International Law Association's Contribution to International Water Resources Law’ (1996) 36 Nat Res J 155.
} 
the abiding antimony between law and fact. ${ }^{165}$ In this light, it seems that the strand of constitutionalism advocated by Peters does not really help us redress the participation gap in global governance, since it espouses the familiar distinction between direct and indirect participation in law-making. This much has been conceded by Kleinlein who acknowledges that ' $[\mathrm{a}] 11$ in all, the methods to accommodate non-State actors within a global constitutional community are rather casual. 166

What is then the added value of viewing questions of broader participation in global governance through a constitutionalist prism? Certainly, the direct/indirect participation model is helpful in so far as it acknowledges an indirect role for non-State actors in decision-making processes at the international level, but it can hardly be seen as offering any new analytical and normative insights. Mainstream legal positivism has long acknowledged the distinction between formal decision-makers and actors that may indirectly influence global decisionmaking processes. Furthermore, the limited role accorded to non-State actors under the participation model propounded by Peters is a far cry from notions of public participation and greater inclusiveness lying at the heart of the quest for alternative theoretical frameworks for addressing the participation gap in the definition of GPGs. Thus, all in all, it seems that attempts to solve the participation problem in the definition of GPGs by invoking global constitutionalism leave much to be desired.

\section{F. CONCLUSION}

The foregoing discussion has shown that the question of inserting democratic and participatory principles in the definition of GPGs remains an abiding one. Core tenets of classic international law (and thus, by extension, of mainstream legal positivism) are able to function in an undemocratic way. Alternative theoretical frameworks for redressing the participation gap in the definition of GPGs, such as global administrative law and global constitutionalism, have little persuasive force upon closer examination. This does not mean that international law is of no relevance to the debate regarding GPGs; the contributions by Schaffer and Bodansky illustrate how international law could contribute to the effective provision of such goods. At

\footnotetext{
${ }^{165}$ As Lauterpacht put it: 'Law is a product of social reality. It cannot lag for long behind facts. This antinomy of law and fact is an abiding problem of jurisprudence.' Hersch Lauterpacht, Recognition in International Law (CUP 1947) 426-427.

166 Thomas Kleinlein, 'Non-State Actors from an International Constitutionalist Perspective: Participation Matters!' in Jean d'Aspremont (ed), Participants in the International Legal System: Multiple Perspectives on Non-State Actors in International Law (Routledge 2011) 47.
} 
the same time, it seems that international law may have less to offer when it comes to the question of integrating democratic and participatory principles in the definition of GPGs.

Attempts to frame the question of the democratic definition of GPGs in legal terms that ignore the tension between democracy and the structure of the international legal system as well as the inadequacy of alternative legal frameworks to satisfactorily address the participation problem in global governance may be seen as symptomatic of the general unease felt by international lawyers to deal with questions of global governance without transferring them into the realm of law. As d'Aspremont aptly remarks: 'It is as if international legal scholars cannot study a phenomenon without portraying it as a legal phenomenon.'167 However, the usefulness of framing all global policy challenges as challenges for international law is doubtful. Such an approach rests on the assumption that international law can bring about all the necessary political and social changes and thus, runs the risk of 'legocentrism' where 'law is treated ... as the natural path to the ideal ... conflict resolution and ultimately to social order guaranteeing peace and harmony.' 168 However, international law is but one of the elements in the transposition of democratic standards (such as public participation in decisionmaking processes) in global governance. As Charlesworth notes, international law:

[I]s a strand in a fabric of regulation where the strength of each strand by itself is rather weak. The strength of the fabric as a whole ... comes from the process of weaving multiple strands together ... We can think of the democratic fabric as including economic, sociological, cultural, historical and legal threads. By themselves each set would have little impact, but woven together they make the fabric more resilient and more beautiful. ${ }^{169}$ The foregoing analysis showed that, presently, the 'international legal thread' is not particularly strong. Thus, instead of shoehorning reality into theoretical frameworks that fall short of convincing, international legal scholars should be more open about the limits of our own discipline and concede that, at this moment in time at least, international law and international legal scholarship are (in and of themselves) of limited assistance when it comes to bridging the participation gap in the definition of GPGs.

This conclusion by no means implies that the debate regarding the democratisation process underlying the definition of GPGs should not continue. On the contrary, the debate is an acute reminder of the lingering legitimacy and participation issues in international law.

167 Jean d'Aspremont, 'From a Pluralization of International Law-Making Processes to a Pluralization of the Concept of Law' in Pauwelyn, Wessel and Wouters (eds) (n 97) 199.

${ }^{168}$ Günter Frankenberg, ‘Critical Comparisons: Re-thinking Comparative Law' (1985) 26 Harv Intl L J 441, 445. ${ }^{169}$ Charlesworth (n 46) 142. 
What is then the role of international legal scholars in this debate? Instead of shoehorning reality into theoretical frameworks that find no support in practice, perhaps a more promising approach would be to make States more conscious of the impact that the participation problem has on the legitimacy, authority and continuing relevance of international law as a regulatory mechanism in modern international relations. Widening the scope of international law to integrate new social actors is a project that escapes the academic realm and can only be meaningfully pursued if the key players of the system are willing to adapt to the changing reality of globalisation. In this sense, State consent should not be viewed as an obstacle to progress that somehow needs to be evaded, but rather, as the only realistic means of tackling the challenges of globalisation. 